ISSN 1112-9867

Available online at http://www.jfas.info

\title{
EFFECT OF ORGANIC EXTRACTS OF BUNIUM INCRASSATUM ON THE HEMATOLOGICAL, OVARIAN AND UTERINE PARAMETERS OF MATURE FEMALE RABBIT
}

\author{
S. Chentouh ${ }^{1}$, S. Boulahbel ${ }^{1 *}$, A. Ouldjaoui ${ }^{2}$, N. Hammoudi ${ }^{1}$, H. Djebaili ${ }^{1}$, F. $_{\text {Adjal }}{ }^{2}$ \\ ${ }^{1}$ Laboratoire des Biomolécules Végétales et Amélioration des Plantes, Université \\ d'Oum El Bouaghi, Algérie \\ ${ }^{2}$ Laboratoire des Ressources Naturelles et Aménagement des milieux sensibles, Université \\ d'Oum El Bouaghi, Algérie
}

Received: 10 June 2017 / Accepted: 25 August 2017 / Published online: 01 September 2017

\begin{abstract}
This work aims to evaluate the effect of the organic extracts of Bunium incrassatum roots on some hematological parameters and histological changes of the genital tract. The study was achieved on mature rabbits of the local breed for 15 days. The animals were divided into five groups, which have daily administered $0,25,50,100$ and $200 \mathrm{mg} / \mathrm{kg} /$ day doses, respectively. The group with dose 0 was taken as a control. After treatment, the rabbits were sacrificed. The rabbit blood was collected in heparin tubes and their ovaries and uterus were removed, fixed in $10 \%$ formalin; and stained with hematoxylin-eosin. The treatment induces a significant decrease in the level of Triglyceride, Cholesterol and a significant increase in the number of growing follicles accompanied by a decrease in atretic follicles, compared to the control group. The study shows that the organic extract of B. Incrassatum has estrogenic effects.
\end{abstract}

Keywords: Bunium incrassatum, Organic extract, Rabbits, Ovaries, Follicles, Liver, Uterus

Author Correspondence, e-mail: souboulahbel@yahoo.fr

doi: http://dx.doi.org/10.4314/jfas.v9i3.23 


\section{INTRODUCTION}

Algeria is one of the countries that are rich in Medicinal plants that must be exploiting for their use in different fields. Today, plants are widely used and especially recommended by therapists and public health organizations, such as the World Health Organization [1]. Based on traditional uses, many researchers have tried to deepen knowledge on medicinal plants and their impact on human and animal health.

Bunium is a plant genus which belongs to the Apiaceae family, with 45 to 50 species. This genus is close to Carum genus. Both are two of the most important aromatic and medicinal plants in Algeria. The genus Bunium consists of seven species, four of which are endemic. Bunium incrassatum is widely distributed in the east parts of Algeria and locally called "Talghouda" [2].

The roots of $B$. incrassatum are quite nutritious and usually eaten like potatoes, but often they are consumed directly raw. In the indigenous system of medicines, dried and powdered tubers are used as astringent anti-diarrheic or against inflammatory hemorrhoids. Also, they are used for bronchitis and cough treatment. According to traditional healers, B. incrassatum is also used for the purpose of increasing the weight and milk secretion of some farm animals. Investigation about phytochemical of $B$. incrassatum indicates the presence of sucrose, oleic acid, scopoletin, scoparone and $\beta$-sitosterol [3]. However, to the best of our knowledge to date, there is no research on the impact of extracts of this plant on animal physiology including biology of animal reproduction. From the above, in our research, we will study specifically the effects of the organic extract of this plant on some histological changes in liver, the ovary and uterus of the mature rabbits of Algerian population.

\section{MATERIALS AND METHODS}

\subsection{Biological Material}

The roots of Talghouda (Bunium Incrassatum) were collected in September 2015. They have been identified by an expert in botany. Plants were washed thoroughly with water. Roots and aboveground plant parts were separated. Roots were dried at room temperature for a few days and ground into fine powder.

\subsection{Preparation of the extract}

One hundred grams $(100 \mathrm{~g})$ of powder are macerated in $100 \mathrm{ml}$ of ethanol and $100 \mathrm{ml}$ of chloroform for 24 hours in the shade. The homogenate obtained is filtered on Wattman chromatography paper $3 \mathrm{MM}$. After evaporation of the filtrate obtained using a rotary 
evaporator of the BUCHI type at $60^{\circ} \mathrm{C}$, we obtain $3 \mathrm{ml}$ of a brown liquid which serves to prepare the organic extract. This liquid is diluted in distilled water.

\subsection{Animal equipment}

The animals used in this study are composed of 30 rabbits (Oryctolagus cuniculus), sexually matured average body weights between 1.6 and $2.2 \mathrm{~kg}$. These rabbits were grouped in specific cages $(50 \times 60 \times 53 \mathrm{~cm})$, screened, provided by drinking troughs of water. The breeding was carried out in the animal house of the technical institute of breeding, Hamma Bouziane Constantine under natural (control) conditions (temperature, photoperiod and humidity). The rabbits are fed daily on a standard complete diet in the form of granules.

\subsection{Treatment methods}

A number of 30 animals were divided into 5 equal groups of rabbits. The control and treated animals were weighed in $\mathrm{g}( \pm 0.01 \mathrm{~g})$ every two days throughout the treatment period in order to evaluate the effect of the extract of this plant on the mature rabbit. The extract was diluted by distilled water and administered daily by gavages. The treatments were achieved by the administration of doses of: $0,25,50,100$ and $200 \mathrm{mg} / \mathrm{kg} /$ day resulting in the distribution of the rabbits in five groups: Control (T), G1, G2, G3 and G4, respectively.

\subsection{Sacrifice and Blood collection}

The treatment lasted for 15 days, the rabbits were sacrificed the day after the last gavage. The blood is immediately collected in two polyethylene tubes, one contains the anticoagulant EDTA (Ethylene Diamine Tetra-Acetic), and the other haemolysis without anticoagulant; the latter is centrifuged at $3000 \mathrm{Rpm}$ for 15 minutes. After the centrifugation, the blood obtained serum is kept in tubes at a temperature of less than $-4{ }^{\circ} \mathrm{C}$ for the analysis of the various biochemical parameters; Cholesterol (CHOL), triglycerides (TG) and HDL (High-density lipoprotein), LDL (Low-density lipoprotein). Also, blood was placed in tubes containing EDTA for hematological analysis.

After the animal was sacrificed, the organs were removed from the adipose tissue and weighted in $g( \pm 0.001 \mathrm{~g})$. They were fixed in Formalin $10 \%$ for histological studies. The relative weight (RW) of each organ was determined by the following formula:

$$
\text { Relative weight }(g / 100 g)=\frac{\text { Organ weight }(g)}{\text { Body weight }(g)} \times 100
$$

\subsection{Statistical Analysis}

The statistical evaluation is performed by the student's $\mathrm{T}$ test. The results are given in the form of averages and standard deviations (SD) relative to 30 adult rabbits divided into five 
groups of 6 rabbits, using SPSS software, version 20.0 and Excel 2016. Comparison or correlation is considered, according to the probability (p), as follows:

Not significant if $p>0.05$, significant $(*)$ if $p<0.05$, highly significant $(* *)$ if $p<0.01$ and very highly significant $(* * *)$ if $\mathrm{p}<0.001$.

\subsection{Microscope photography}

The photomicrographs were conducted with an optical microscope (B-150 OPTIKA) equipped with a digital camera.

\section{RESULTS}

\subsection{General condition of animals}

Throughout the experimental period, the animals showed normal behavior either in the control or treated batches. No toxic effects were observed for all the experimental groups after treatment with all doses.

\subsection{Evolution of body weight}

The results shown in Table 1 reveal the evolution of gain weight following the effect of daily administration for two weeks of $25,50,100$ and $200 \mathrm{mg} / \mathrm{kg} /$ day of organic extract of B. incrassatum to mature rabbits. The effect of the extract on the body weight is illustrated. In the treated and control animals, we note an increase in the final body weight as compared to the initial body weight but it isn't statistically significant. The administration of the extract decreases the weight gain compared to the control $(\mathrm{T})$. We find weight reduction of $13.11 \%$ in $\mathrm{G} 1 ; 18.32 \%$ in $\mathrm{G} 2 ; 15.88 \%$ in G3 and $12.13 \%$ in G4 compared to control, which is $18.42 \%$.

Table 1. Body weight variation in the control and treated batches

\begin{tabular}{|c|c|c|c|c|c|}
\hline \multirow{3}{*}{ Parameters } & \multicolumn{5}{|c|}{ Experimental batches } \\
\hline & Control (T) & G1 & G2 & G3 & G4 \\
\hline & Mean \pm S.D. & Mean \pm S.D. & Mean \pm S.D. & Mean \pm S.D. & Mean \pm S.D. \\
\hline Initial body & $2607.33 \pm 192$ & $2150 \pm 180^{\mathrm{NS}}$ & $1850 \pm 150^{\mathrm{NS}}$ & $2027 \pm 127.5^{\mathrm{NS}}$ & $2500 \pm 130^{\text {NS }}$ \\
\hline weight (g) & - & $(-17.53 \%)$ & $(-29.04 \%)$ & $(-22.25 \%)$ & $(-4.11 \%)$ \\
\hline Final body & $3092 \pm 207.5$ & $2430 \pm 165^{\mathrm{NS}}$ & $2182.3 \pm 222^{\mathrm{NS}}$ & $2350 \pm 140^{\mathrm{NS}}$ & $2805 \pm 260^{\mathrm{NS}}$ \\
\hline weight ( $g$ ) & - & $(-21.41 \%)$ & $(-29.42 \%)$ & $(-24.00 \%)$ & $(-9.29 \%)$ \\
\hline Weight gain & $485.00 \pm 101$ & $280 \pm 85^{\mathrm{NS}}$ & $332.3 \pm 57.50^{\mathrm{NS}}$ & $322.67 \pm 42.5^{\mathrm{NS}}$ & $406.67 \pm 60^{\mathrm{NS}}$ \\
\hline (g) & - & $(-42.32 \%)$ & $(-31.55 \%)$ & $(-33.53 \%)$ & $(-16.13 \%)$ \\
\hline $\begin{array}{l}\text { Rate of } \\
\text { increase }\end{array}$ & $+18.42 \%$ & $+13.11 \%$ & $+18.32 \%$ & $+15.88 \%$ & $+12.13 \%$ \\
\hline
\end{tabular}




\subsection{Evolution of organs weight}

The obtained results (Table 2) show that oral administration of the organic extract for 15 days induce a highly significant increase in the relative weight of reproductive system in G1 and G3 $(p<0.01)$ compared to the control groups and a significant increase $(p<0.05)$ in G2 and G4 compared to the control. However, we notice a highly significant increase $(p<0.01)$ in relative weight of ovary in G3, and G4, and significant increase $(p<0.05)$ in G1 compared to the control. We also observed not statistically significant $(p>0.05)$ in relative weight of liver in treated animals, in comparison with the control one.

Table 2. Evolution of the relative weights (RW) of some organs in the control and the treated rabbits

\begin{tabular}{|c|c|c|c|c|c|}
\hline \multirow{2}{*}{ Parameters } & \multicolumn{5}{|c|}{ Experimental batches } \\
\cline { 2 - 6 } & Control (T) & G1 & G2 & G3 & G4 \\
\cline { 2 - 7 } & Mean \pm S.D. & Mean \pm S.D. & Mean \pm S.D. & Mean \pm S.D. & Mean \pm S.D. \\
\hline Reproductive & $0.316 \pm 0.003$ & $0.490 \pm 0.014^{* * *}$ & $0.460 \pm 0.028^{*}$ & $0.540 \pm 0.028^{* * *}$ & $0,580 \pm 0.042^{* *}$ \\
system $(\mathrm{g} / 100 \mathrm{~g})$ & - & $(+55.06 \%)$ & $(+45.56 \%)$ & $(+70.88 \%)$ & $(+83.54 \%)$ \\
\hline Ovary $(\mathrm{g} / 100 \mathrm{~g})$ & $0.004 \pm 0.001$ & $0.007 \pm 0.003^{* *}$ & $0.006 \pm 0.003^{\mathrm{NS}}$ & $0.009 \pm 0.001^{* * *}$ & $0,008 \pm 0.001^{* * *}$ \\
& - & $(+80 \%)$ & $(+50 \%)$ & $(+112.5 \%)$ & $(+92.5 \%)$ \\
\hline \multirow{2}{*}{ Liver $(\mathrm{g} / 100 \mathrm{~g})$} & $4.190 \pm 0.014$ & $3.600 \pm 0.042^{* * * *}$ & $4.05 \pm 0.13^{\mathrm{NS}}$ & $4.210 \pm 0.042^{\mathrm{NS}}$ & $4.190 \pm 0.028^{\mathrm{NS}}$ \\
& - & $(-14.08 \%)$ & $(-3.34 \%)$ & $(+0.47 \%)$ & $(0 \%)$ \\
\hline
\end{tabular}

\subsection{Effect of the organic extract of Bunium incrassatum on biochemical parameters of blood}

The results obtained for the four lipid parameters monitored (triglyceride, total cholesterol, LDL and HDL) are shown in Table 3 and. Fig. 01. 
Table 3. Evolution of some lipid parameters (triglycerides, cholesterols, HDL, LDL) in the control and treated rabbits with the organic extract of Bunium Incrassatum roots

\begin{tabular}{|c|c|c|c|c|c|}
\hline \multirow{2}{*}{ Parameters } & \multicolumn{5}{|c|}{ Experimental batches } \\
\cline { 2 - 6 } & Control (T) & G1 & G2 & G3 & G4 \\
\cline { 2 - 7 } & Mean \pm S.D. & Mean \pm S.D. & Mean \pm S.D. & Mean \pm S.D. & Mean \pm S.D. \\
\hline Triglyceride & $1.64 \pm 0.04$ & $1.20 \pm 0.028^{*}$ & $1.18 \pm 0.03^{*}$ & $0.6 \pm 0.071^{* * *}$ & $0.88 \pm 0.11^{* * *}$ \\
(TG) (g/1) & & $(-26.83 \%)$ & $(-28.05 \%)$ & $(-63.41 \%)$ & $(-64.34 \%)$ \\
\hline Cholesterol & $1.080 \pm 0.042$ & $1.030 \pm 0.014^{*}$ & $0.940 \pm 0.057^{*}$ & $0.68 \pm 0.042^{* * *}$ & $1.11 \pm 0.09^{*}$ \\
(CHOL) (g/l) & & $(-4.62 \%)$ & $(-12.87 \%)$ & $(-37.04 \%)$ & $(+1.85 \%)$ \\
\hline \multirow{2}{*}{ HDL (g/l) } & $0.470 \pm 0.042$ & $0.420 \pm 0.028^{\text {NS }}$ & $0.500 \pm 0.078^{\mathbf{N S}}$ & $0.44 \pm 0.085^{\text {NS }}$ & $0.39 \pm 0.06^{\text {NS }}$ \\
& & $(-10.63 \%)$ & $(+6.38 \%)$ & $(-6.38 \%)$ & $(-17.02 \%)$ \\
\hline \multirow{2}{*}{ LDL (g/l) } & $0.29 \pm 0.16$ & $0.30 \pm 0.10^{\mathbf{N S}}$ & $0.41 \pm 0.01^{* * *}$ & $0.27 \pm 0.09^{\mathbf{N S}}$ & $0.15 \pm 0.07^{* * *}$ \\
& & $(+3.45 \%)$ & $(+41.37 \%)$ & $(-6.8 \%)$ & $(-48.27 \%)$ \\
\hline
\end{tabular}

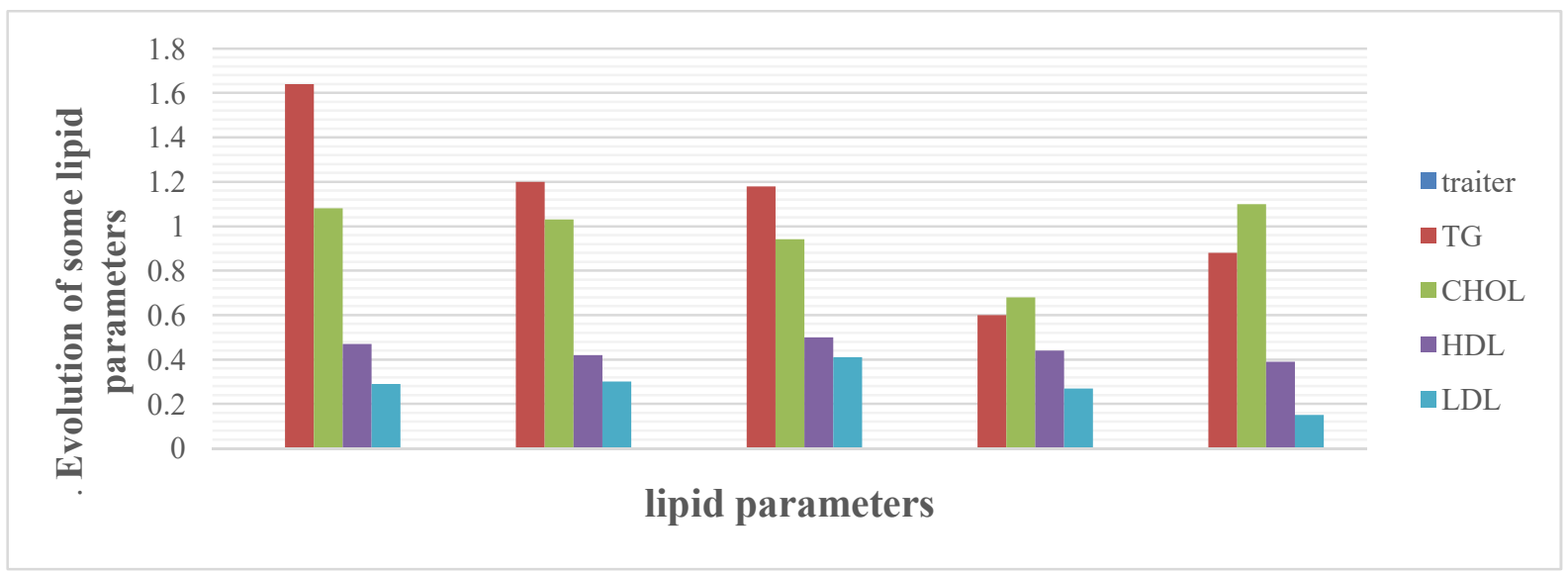

Fig.1. Evolution of some lipid parameters (triglyceride, cholesterol, HDL, LDL.) in nonpregnant rabbits treated with the organic extract of the "Bunuim Incrassatum" roots for 15 days.

The results shown in Table 3 and Fig. 1 revealed that oral administration of the organic extract causes a very highly significant decrease $(p<0.001)$ in TG by $63.41 \%$ and $64.34 \%$ G3 and G4 respectively, and significant decrease by $26.83 \%$; $28.05 \%$, in G1, G2 respectively, compared to the control ones. Also, we observed a significant decrease $(p<0.05)$ of the total cholesterol with $4.62 \%, 12.87 \%$, respectively, in rabbits treated with the following doses: 25, 50 and; and very highly significant decrease $(\mathrm{p}<0.001)$ by $37.04 \%$, in G3. On the other hand, we notice a pointed significant increase $(p<0.05)$ of CHOL $(+1.85 \%)$ in G4 compared to the control rabbits group. The treatment causes a not significant decrease $(p>0.05)$ of 
HDL and a high significant decrease $(\mathrm{p}<0.01)$ of LDL in treated animals G2 and G4 compared to the control group.

\subsection{Histological changes}

\subsubsection{Change in the ovary}

The follicles numbers present in ovaries of rabbits treated are presented in Table 4 and Fig 2. The results show a very high significant increase $(\mathrm{p}<0.001)$ of $84.13 \%$ in the total number of follicles for G2 and G3 groups treated with 50 and $100 \mathrm{mg} / \mathrm{kg} /$ day doses, respectively, compared to the other groups. There is also a significant increase $(p<0.05)$ in the number of primary follicles in G2, G3 with 95,36\%, and $76.83 \%$, respectively.

Table 4. Numbers of follicles present in ovaries of rabbit after treatment with the organic extract of Bunium incrassatum roots

\begin{tabular}{|c|c|c|c|c|c|}
\hline \multirow{3}{*}{ Parameters } & \multicolumn{5}{|c|}{ Experimental batches } \\
\cline { 2 - 6 } & Control(T) & G1 & G2 & G3 & G4 \\
\cline { 2 - 6 } & Mean \pm S.D. & Mean \pm S.D. & Mean \pm S.D. & Mean \pm S.D. & Mean \pm S.D. \\
\hline $\begin{array}{c}\text { Primary } \\
\text { follicles }\end{array}$ & $36 \pm 2.28$ & $\begin{array}{c}29 \pm 1.70^{\text {NS }} \\
(-19 \%)\end{array}$ & $\begin{array}{c}70.33 \pm 1.41^{*} \\
(+95.36 \%)\end{array}$ & $\begin{array}{c}63.66 \pm 2.12^{*} \\
(+76.83 \%)\end{array}$ & $\begin{array}{c}19.66 \pm 1.71^{\text {NS }} \\
(46.30 \%)\end{array}$ \\
\hline $\begin{array}{c}\text { Secondary } \\
\text { Follicles }\end{array}$ & - & $25.33 \pm 2.12^{*}$ & $39 \pm 1.41^{*}$ & $43 \pm 1.41^{*}$ & $19 \pm 1.23^{\text {NS }}$ \\
$(+4.12$ & $(+49 \%)$ & $(+129.41 \%)$ & $(+152.94 \%)$ & $(+11.76 \%)$ \\
\hline $\begin{array}{c}\text { Growing } \\
\text { Follicles }\end{array}$ & $7 \pm 1.41$ & $\begin{array}{c}5 \pm 1.52^{* * *} \\
(-28.57 \%)\end{array}$ & $\begin{array}{c}10 \pm 1.37^{\text {NS }} \\
(+42.85 \%)\end{array}$ & $\begin{array}{c}11 \pm 1.62^{* * *} \\
(+57.14 \%)\end{array}$ & $\begin{array}{c}3 \pm 1.52^{* * *} \\
(-57.14 \%)\end{array}$ \\
\hline $\begin{array}{c}\text { Total number } \\
\text { of Follicles }\end{array}$ & $77.66 \pm 3.50$ & $\begin{array}{c}68.33 \pm 2.56^{\text {NS }} \\
(-12.01 \%)\end{array}$ & $\begin{array}{c}143 \pm 1.73^{* * *} \\
(+84.13 \%)\end{array}$ & $\begin{array}{c}143 . \pm 2.00^{* * *} \\
(+84.13 \%)\end{array}$ & $\begin{array}{c}56.66 \pm 1.15^{\text {NS }} \\
(-27.04 \%)\end{array}$ \\
\hline
\end{tabular}

In addition, a very highly significant increase $(\mathrm{p}<0.001)$ in the number of growing follicles in G3 with $57.14 \%$, and a very highly significant decrease $(\mathrm{p}<0.001)$ in G1, G4 by $28.57 \%$, $57.14 \%$, respectively, is observed, compared to the control group accompanied with a significant increase $(p<0.05)$ in secondary follicles in G1, G2 and G3. 


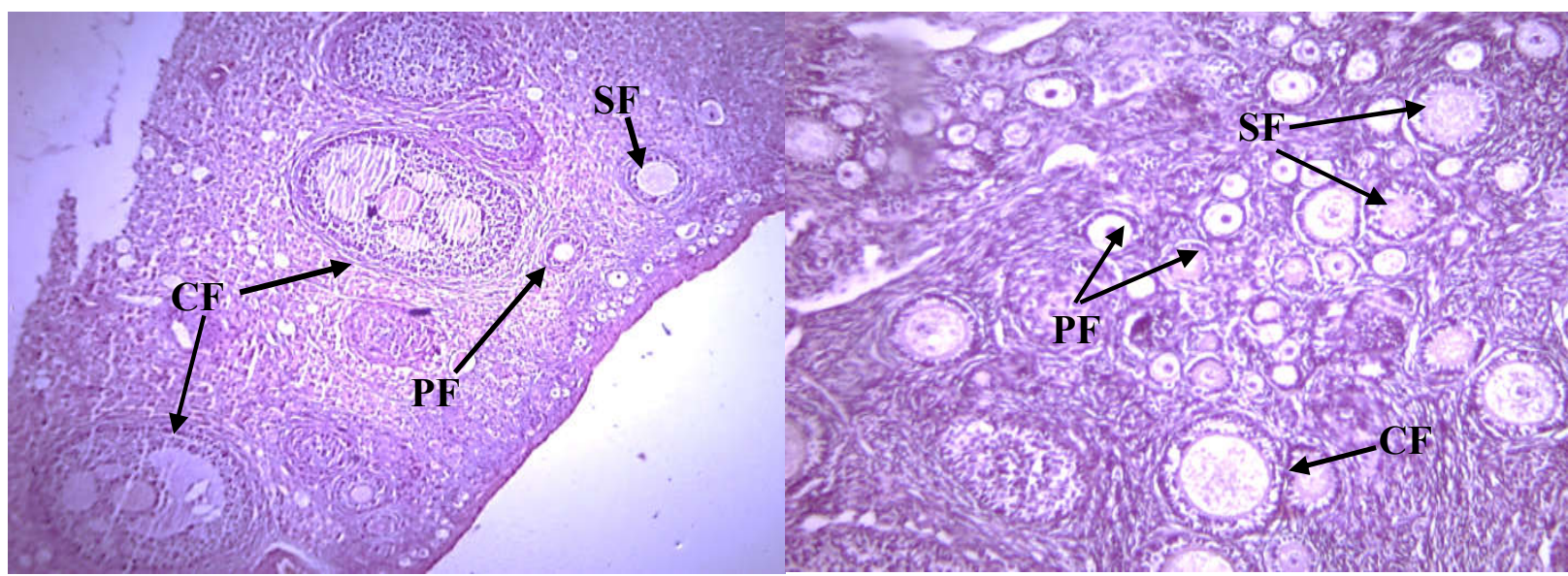

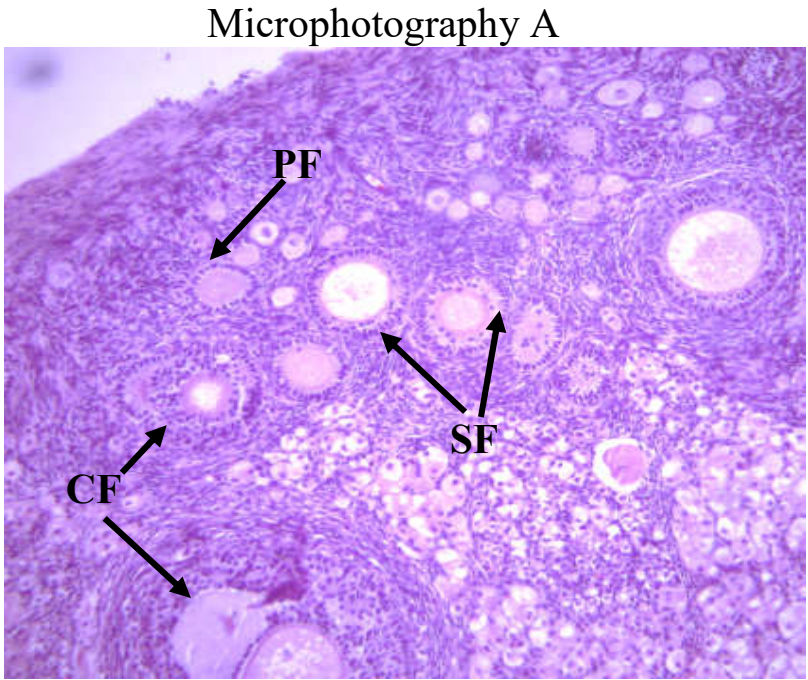

Microphotography C

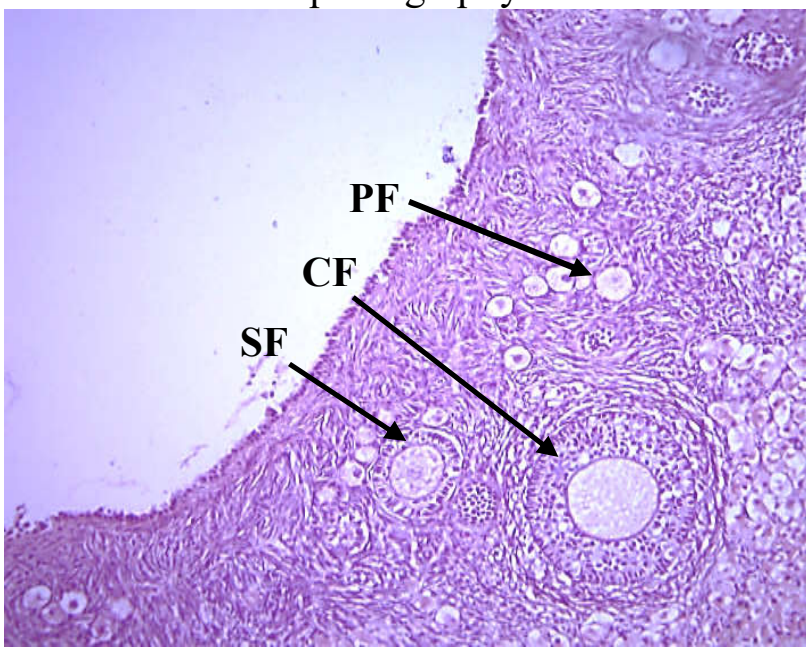

Microphotography E
Microphotography B

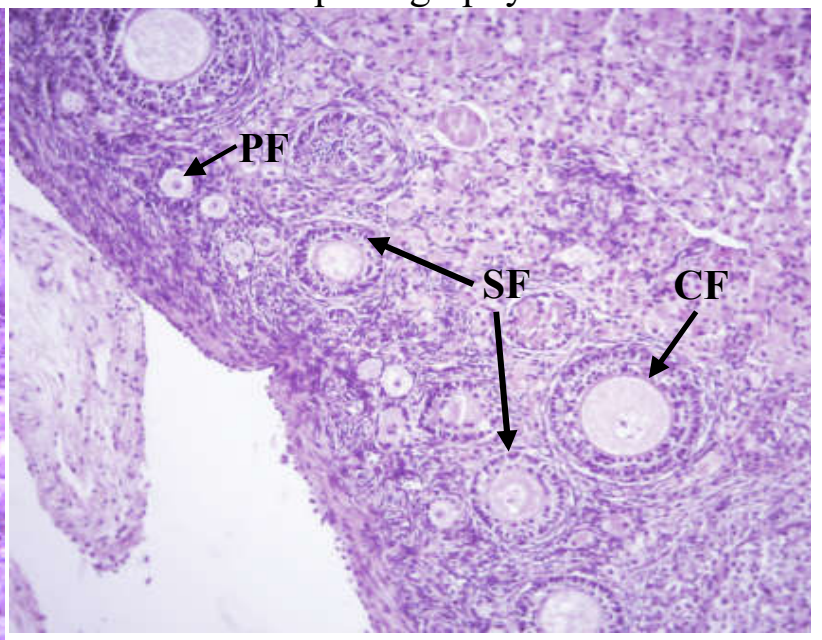

Microphotography D

A, B, C, D and E: (X180).

A (control),

B (treated with $25 \mathrm{mg} / \mathrm{kg} /$ day),

$\mathrm{C}$ (treated with $50 \mathrm{mg} / \mathrm{kg} /$ day),

D (treated with $100 \mathrm{mg} / \mathrm{kg} / \mathrm{day}$ ),

E (treated with $200 \mathrm{mg} / \mathrm{kg} /$ day).

CF: Cavitary follicle.

SF: Secondary follicle.

PF: Primary follicle.

Fig.2. Histological sections of the cortical ovary of rabbit showing different forms of follicles

\subsubsection{Change in atretic follicles}

A decrease in the percentage of atretic follicles of rabbits is noted in the treated G1, G2 and G3 with $10.24 \%, 10.84 \%, 10.84 \%$, respectively, compared to the control group with $18 \%$. 
However, in group treated with $200 \mathrm{mg} / \mathrm{kg} /$ day we record $15.88 \%$ of atretic follicles (Table 5 and Fig. 3).

Table 5. Mean number of atretic follicles present in the ovaries of rabbit after treatment with Bunium incrassatum roots extract.

\begin{tabular}{|c|c|c|c|c|c|}
\hline \multirow{2}{*}{ Parameters } & \multicolumn{5}{|c|}{ Experimental batches } \\
\cline { 2 - 6 } & Control (T) & G1 & G2 & G3 & G4 \\
\cline { 2 - 6 } & Mean \pm S.D. & Mean \pm S.D. & Mean \pm S.D. & Mean \pm S.D. & Mean \pm S.D. \\
\hline $\begin{array}{c}\text { Atretic } \\
\text { Follicles }\end{array}$ & $14 \pm 2$ & $\begin{array}{c}7 \pm 1.5^{\text {NS }} \\
(-50 \%)\end{array}$ & $\begin{array}{c}15 \pm 2.5^{\text {NS }} \\
(+7.14 \%)\end{array}$ & $\begin{array}{c}15 \pm 2^{\text {NS }} \\
(+7.14 \%)\end{array}$ & $\begin{array}{c}9 \pm 1.5^{\text {NS }} \\
(-35.71 \%)\end{array}$ \\
\hline $\begin{array}{c}\text { Total number } \\
\text { of Follicles }\end{array}$ & $77.66 \pm 1.5$ & $\begin{array}{c}68.33 \pm 0.57^{\text {NS }} \\
(-12.01 \%)\end{array}$ & $\begin{array}{c}143 \pm 1.73^{* * *} \\
(+84.13 \%)\end{array}$ & $\begin{array}{c}143 \pm 2.04^{* * *} \\
(+84.13 \%)\end{array}$ & $\begin{array}{c}56.66 \pm 1.15^{\text {NS }} \\
(-27.04 \%)\end{array}$ \\
\hline $\begin{array}{c}\text { \% Atretic } \\
\text { Follicles }\end{array}$ & $18.02 \%$ & $10.24 \%$ & $10.84 \%$ & $10.84 \%$ & $15.88 \%$ \\
\hline
\end{tabular}




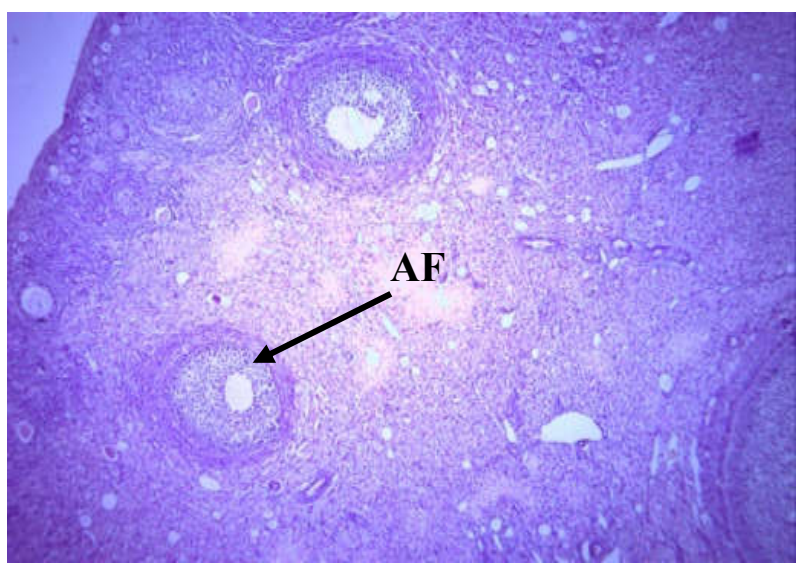

Microphotography A

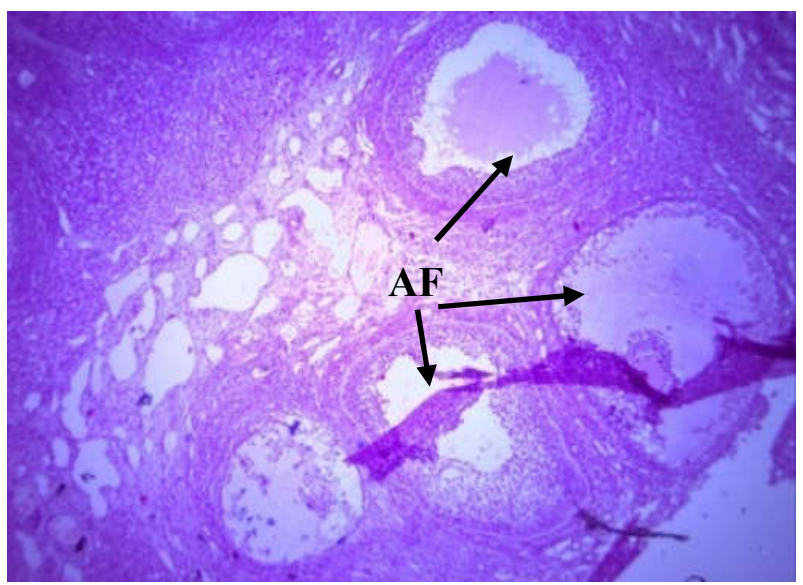

Microphotography C

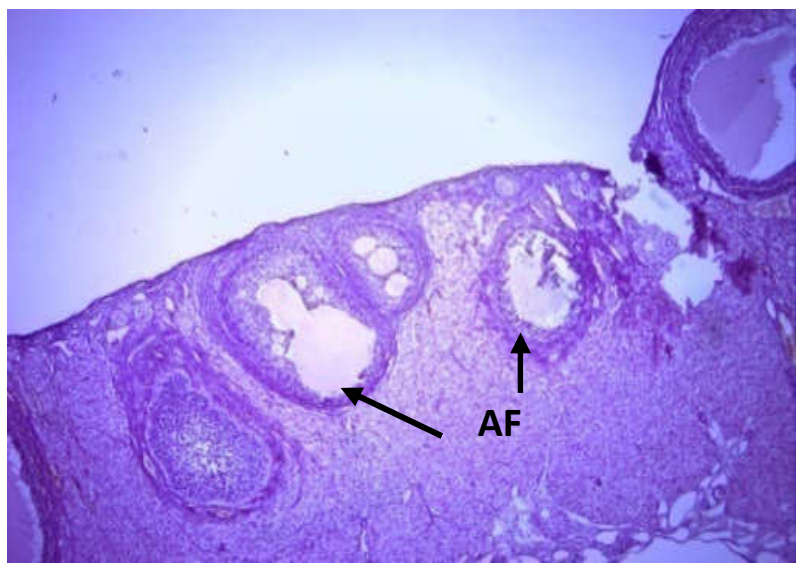

A, B, C, D and E: (X180).

A (control),

B (treated with $25 \mathrm{mg} / \mathrm{kg} /$ day),

$\mathrm{C}$ (treated with $50 \mathrm{mg} / \mathrm{kg} /$ day),

D (treated with $100 \mathrm{mg} / \mathrm{kg} / \mathrm{day}$ ),

E (treated with $200 \mathrm{mg} / \mathrm{kg} /$ day).

AF: Atretic Follicle.

Microphotography E

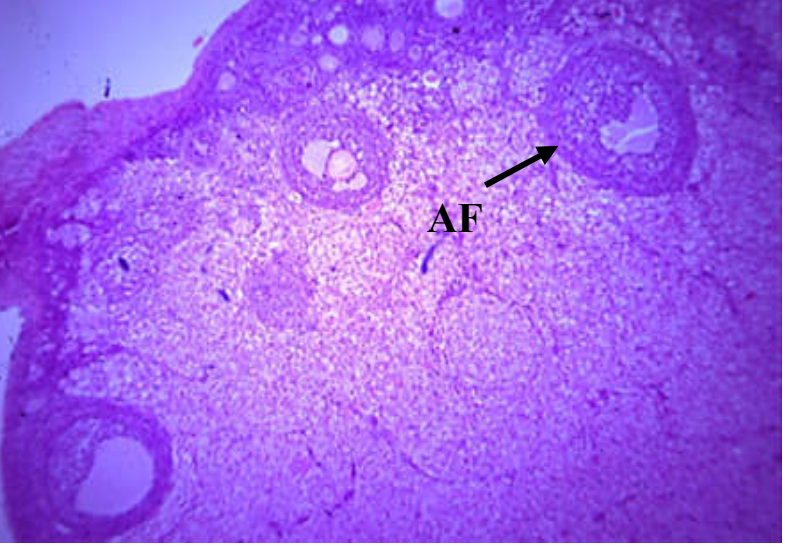

Microphotography B

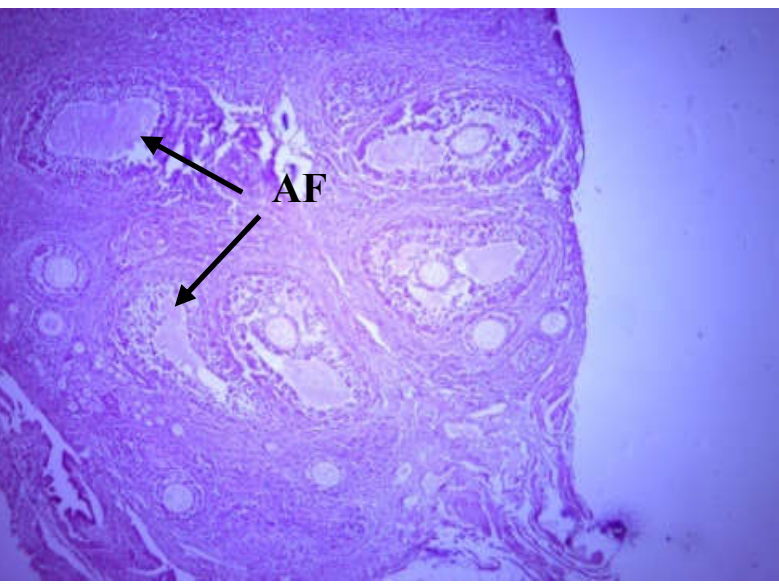

Microphotography D

Fig.3. An ovarian section showing different types of atretic follicles of rabbit 


\subsubsection{Change in uterus}

The microphotographs of Fig. 4 represent histological changes in the uterus of the control rabbits $\mathrm{A}$ and treated animals $\mathrm{B}, \mathrm{C}, \mathrm{D}, \mathrm{E}$. These microphotographs show well developed mucosa and abundance of endometrial glands. The structural changes in uterine tissue observed in treated animals could be attributed to substances contained in the extract of

\section{B. incrassatum}

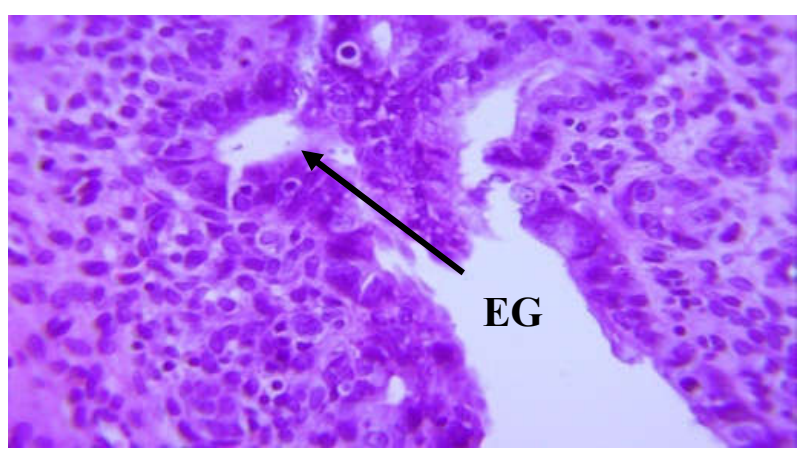

Microphotography A

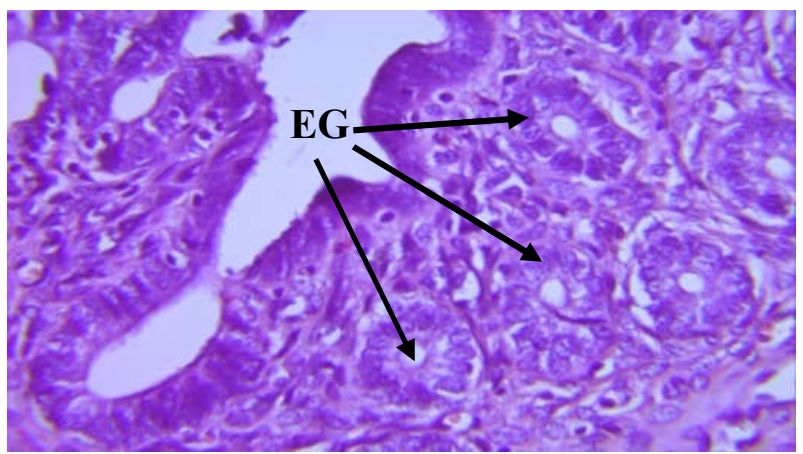

Microphotography C

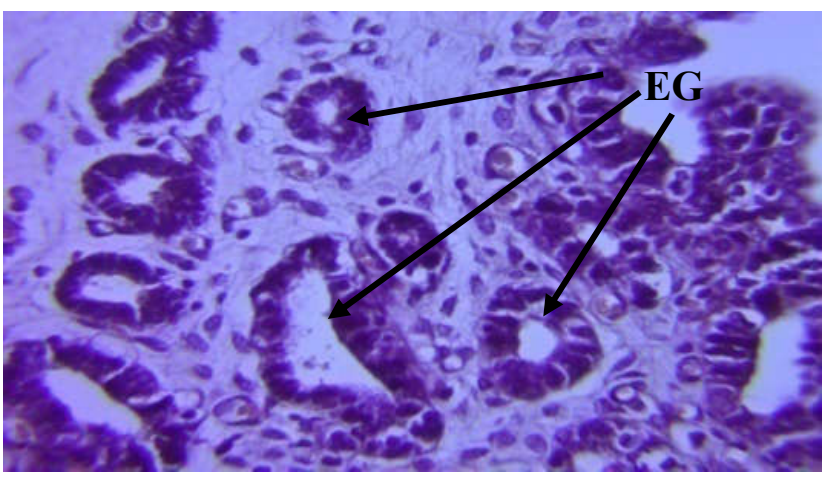

Microphotography E

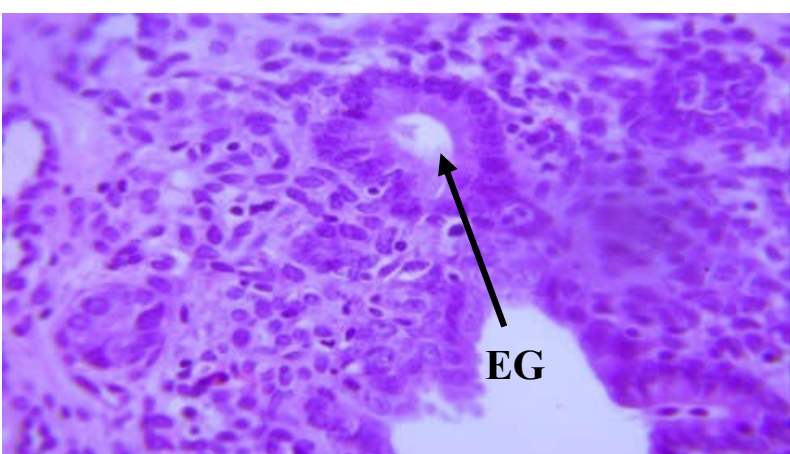

Microphotography B

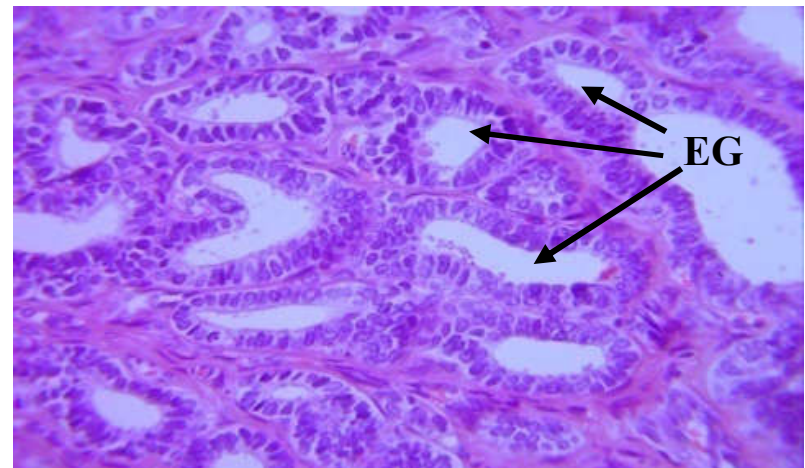

Microphotography D

A, B, C, D and E: (X180).

A (control),

B (treated with $25 \mathrm{mg} / \mathrm{kg} /$ day),

$\mathrm{C}$ (treated with $50 \mathrm{mg} / \mathrm{kg} /$ day),

D (treated with $100 \mathrm{mg} / \mathrm{kg} / \mathrm{day}$ ),

E (treated with $200 \mathrm{mg} / \mathrm{kg} /$ day).

EG: Endometrial glands.

Fig.4. Longitudinal section in uterine horn of mature female rabbit showing changes in the uteri associated with daily administration of Bunium incrassatum extract control (A) and treated $(\mathrm{B}, \mathrm{C}, \mathrm{D}, \mathrm{E})$ 


\section{DISCUSSION}

The objective of this work is to evaluate the effect of the treatment of mature female rabbits by organic extract of $B$. incrassatum. The rabbits were classified in 5 groups (Control, G1, G2, G3 and G4) with respect to the 5 doses of $0,25,50,100$ and $200 \mathrm{mg} / \mathrm{kg} / \mathrm{day}$, respectively, administrated during 15 days. The phytochemical analysis of roots of the plant revealed the presence of some bioactive compounds (sucrose, oleic acid, scopoletin, scoparone and $\beta$ sitosterol). The increase in the final body weight of mature rabbits compared to their initial weight was not statistically significant: $13.11 \%$ for G1, $15.88 \%$ for G3 and $12.33 \%$ for G4, but for G2 and the control group the increase was more important with $18.32 \%$ and $18.47 \%$, respectively. A similar result was found by Bakura S. et al. (2012) [4], who have studied the inclusion of $0,15,30,45$ and $60 \%$ Daucus carota leaf meal in the concentrated diet in five batches of rabbits and demonstrated that rabbits treated with $15 \%$ had the greatest weight and the gain ratio was not significantly different from $0 \%$. They concluded that dried carrot leaf meal can be incorporated up to $15 \%$ in the feed of growing rabbits without any adverse effect on their performance. This will be due that $B$. incrassatum and D. carota belong to the same family of Apiaceae [4].

The results of the present study showed also a highly significant increase in the relative weight of reproductive system in G1 and G3 $(\mathrm{p}<0.01)$ compared to the control groups and a significant increase $(\mathrm{p}<0.05)$ in G2 and G4 compared to the control. However, we notice a highly significant increase $(p<0.01)$ in relative weight of ovary in G3 and G4; and significant increase $(\mathrm{p}<0.05)$ in G1 compared to the control. We also observed not statistically significant $(\mathrm{p}>0.05)$ in relative weight of liver in treated animals, in comparison with the control one This is in agreement with the results of Mohaissen, H Adaay et al. (2013) [6] who showed that treatment with the extract of Medicago saliva and Salvia officinalis increases the weight of reproductive organs. Our results are also similar with those of Balé Bayala et al. [5], who found that treatments of rats using doses of 100 and $200 \mathrm{mg}$ per $\mathrm{kg}$ of Holarrhena floribunda, have induced a very high significant increase $(\mathrm{p}<0.001)$ of the fresh weight of the uterus as well as the augmentation of endometrial glands.

We can explain this augmentation by the presence of oleic acid and scopoletin in the extract of B. incrassatum. Chen Z. J. et al. (2004) [7] proved that the supplementation of oleic acid induces production of prostaglandin in maternal endometrial and Choi B R et al. (2015) [8] reported that the perfusion with scopoletin lead to significant increase in cyclic adenosine monophosphate. It is well known that the gonadotropins FSH and LH act on their target cells 
via their specific membrane receptors, respectively FSHR and LHR. The activation of these receptors by their ligands stimulates the production of cAMP [9].

The present study demonstrates that oral administration of the organic extract for 15 days causes a very highly significant decrease $(\mathrm{p}<0.001)$ in TG by $63.41 \%$ and $64.34 \%$ in G3 and G4 respectively, and significant decrease by $26.83 \%$ and $28.05 \%$, in G1 and G2 respectively, compared to the control T. Also, we observed a significant decrease $(\mathrm{p}<0.05)$ of the total cholesterol with $4.62 \%, 12.87 \%$ respectively, in rabbits treated with the following doses: $25,50 \mathrm{mg} / \mathrm{kg} / \mathrm{day}$; and very highly significant decrease $(\mathrm{p}<0.001)$ by $37.04 \%$, in G3. On the other hand, we notice a pointed significant increase $(p<0.05)$ of CHOL $(+1.85 \%)$ in G4 compared to the control rabbits group. The treatment causes a not significant decrease $(p>0.05)$ of HDL and a high significant decrease $(p<0.01)$ of LDL in treated animals G2 and G4 compared to the control group.

The same results were found by CHANGIZI et al. (2013), who demonstrated that the administration of $200 \mathrm{mg} / \mathrm{kg}, 400 \mathrm{mg} / \mathrm{kg}$ and $800 \mathrm{mg} / \mathrm{kg}$ of Portulaca oleracea extract induces a significant decrease in triglyceride and an increase in HDL-c in rats consuming hoppergrass [9]. Several studies suggested that supplementation of the omega-3 fatty acid decreases plasma triglyceride levels and increases HDL-cholesterol [10]. We can explain these results by the presence of $\beta$ sitosterol (one of the components of this plant). Lees A.M. et al. (1977) have demonstrated that beta-sitosterol alone or in combination with similar phytosterols reduces blood cholesterol level [11], and Ikeda et al 1988 and Brufau et al 2008 have proved that plant's sterols as B sitosterol, causes diminution of cholesterol by competitively displacing from micelles and possibly some other lipid-soluble substance from the intestine $[12,13]$. Wong (2001) showed that Beta-sitosterol may lead to a $10 \%$ decrease in total serum cholesterol [14].

It becomes evident from the histological study that the morphological picture of the ovary shows a very high significant increase $(\mathrm{p}<0.001)$ of $84.13 \%$ in the total number of follicles for G2 and G3 groups treated with 50 and $100 \mathrm{mg} / \mathrm{kg} /$ day doses, respectively, compared to the other groups. There is also a significant increase $(p<0.05)$ in the number of primary follicles in G2, G3 with 95,36\%, and $76.83 \%$, respectively.

This effect is due to the presence of sucrose as confirmed by Chen et al (2004), who showed that the addition of sucrose in the cryoprotectant solution is more suitable for human oocyte cryopreservation [7]. We notice here that sucrose is the major compound of B. incrassatum (Bousetla A. et al. 2015) [3]. 
Liti B. (2004) cited that growth hormone (GH) exerts its cell division-stimulating (mitogenic) effect not directly on cells but indirectly through the mediation of a mitogen whose synthesis and release are induced by growth hormone [15]. This mitogen is called insulin-like growth factor I (IGF-I). The secretion and activity of IGF-I can be influenced by the nutritional status of the individual and by many hormones other than GH. Sexual maturation and adult reproductive function are tightly linked to nutritional status [16]. Poretsky et al., 1999, showed that in vitro, insulin stimulates ovarian steroidogenesis by both granulosa and thecal cells, and increasing production of androgens, estrogens, and progesterone. Parra et al. (1995), have examined that the effects of oral or intravenous administration of glucose on circulating androgen concentrations. They found an increase in free testosterone and no change in androstenedione after breakfast in normal women, but a decline of free testosterone after an oral glucose load. [17].

The increase in the number of different types of growing follicles, especially in animals treated with 50 and $100 \mathrm{mg} / \mathrm{kg} /$ day, can be attributed to the effects of estrogen-like substances present in $B$. incrassatum. These results are in agreement with those reported by Khaldoum et al. (2009) [18], who demonstrated that the administration of TRIGONELLA FOENUMGRAECUM extract induces a significant increase in the number of ovarian follicles

In the present investigation, the ratio of the number of atretic follicles to the total number of follicles is less in G1, G2 and G3 (10\%) than in G4 (15\%) and in control group (18\%). This result can be attributed to the negative feedback on the hypothalamic-pituitary-ovarian axis by the high dose (200 mg/kg/day). Monniaux et al. (2009) have demonstrated that follicular development in rabbits is 97 days long, including 10 days for the maturation of antrum follicles [19]. Hulot et al. (1985) proved that the antrum follicles in rabbit, which have not been able to develop until an ovulatory stage, due to the lack of stimulation, regressed after 7 to 10 days [20].

Our preliminary study, performed to evaluate the effect of the treatment by extract of B. incrassatum, is realized for the first time. We conclude that the components of this medicinal plant can, at specific doses, have a positive effect on some hematological and reproductive parameters of animals.

\section{ACKNOWLEDGEMENTS}

We would like to express our gratitude to Khalfaoui Zakaria, director of technical institute of breeding animals, Hamma Bouziane Constantine. 


\section{REFERENCES}

[1] WHO, (World Health Organization) Geneva, Traditional Medicine Strategy 2002 http://www.wpro.who.int/health technology/book who traditional medicine strategy 2002 2005.pdf

[2] Quezel, P., Santa, S. Nouvelle flore de l'Algérie et des régions désertiques et méridionales II, eds du centre national de la recherche scientifique, Paris. 1963.

[3] Bousetla A., Zellagui A., Derouiche K., Rhouati S. Chemical constituents of the roots of Algerian Bunium incrassatum and evaluation of its antimicrobial activity, 2011, Arabian Journal of Chemistry, Volume 8, Issue 3, May 2015, Pages 313-316.

https://doi.org/10.1016/j.arabjc.2011.01.022

[4] Bakura S. Abdu, Grace Esrom Jokthan, Mohammed Rabiu Hassan, Hanwa Yusuf Adamu, Suleiman Makama Yashim, Emmanuel Ikani: Effects of Inclusion Levels of Carrot (Daucus carota) Leaf Meal on Performance of Growing Rabbits, World J Life Sci. and Medical Research 2012, 2 (2): 65

[5] Balé Bayala, Hamidou Hamadou Tamboura (Maria Teresa Rubio Pellicer, Daniel Zongo Amadou Traoré, Lamini Ouédraogo Benoît Malpaux, Laya Sawadogo : Effets oestrogéniques du macéré aqueux des feuilles de Holarrhena fl oribunda (G. Don) Dur \& Schinz chez la rate Ovariectomisée. Biotechnol. Agron. Soc. Environ. 2006, 10 (3), 173 - 180.

[6] Mohaisen H. Adaay, Saad S. Al-Dujaily, Ferial K. Khazzal. Effect of aqueous extract of Medicago sativa and Salvia officinalis mixture on hormonal, ovarian and uterine parameters in mature female mice. J. Mater. Environ. Sci. 4 (4) (2013) 424-433.

[7] Chen Z. J., Li1 M., Li1 Y., Zhao1 L.X., Tang R., Sheng1 Y., Gao1 X., Chang C.H., Feng H.L. Effects of sucrose concentration on the developmental potential of human frozenthawed oocytes at different stages of maturity, Human Reproduction. 2004, Vol.19, No.10 pp. 2345-2349. DOI: 10.1093/humrep/deh442

[8] Choi B. R., Kumar S. K., Zhao C., Zhang L. T., Kim C. Y., Lee S.W., Additive effects of Artemisia capillaris extract and scopoletin on the relaxation of penile corpus cavernosum smooth muscle. International Journal of Impotence Research 27, 225-232 (November/December 2015), doi:10.1038/ijir.2015.23.

[9] Changizi A.S., Zarei A., Taheri S., Rasekh F., Ramazani M., The Effects of Portulaca oleracea Alcoholic Extract on Induced Hypercholesterolemia in Rats. Zahedan 2013, J. Res. Med Sci. Vol. 15(6): 34-39.

[10] Mahmoodi M.R., Kimiagar M., Mehrabi Y. The effects of omega-3 plus vitamin E and vitamin $\mathrm{C}$ plus zinc supplementations on plasma lipids and lipoprotein profile in 
postmenopausal women with type 2 diabetes Persian Nutr. Sci. Food Technol. 2009, Vol. 4(3): 1 https://doi.org/10.1177/2042018814548028

[11] Lees A.M., Mok H.Y. Plant sterols as cholesterol-lowering agents : clinical trial in patients with hypercholesterolemia and studies of sterol balance, Atherosclerosis, 1977, $28: 325-38$

[12] Ikeda I., Tanaka. Sugano M. Inhibition of cholesterol absorption in rats by plants sterols. J Lipid Res. 1988, 29. 1573-1582,

[13] Brufau G, Canela MA, Rafecas M. Phytosterols: physiologic and metabolic aspects related to cholesterol-lowering properties. Nutr Res. 2008 Apr;28(4):217-25.

[14] Wong NC. The beneficial effects of plant sterols on serum cholesterol, Can 2001, Jun; $17(6): 715-21$.

[15] Liti B. Effects of Sucrose Supplementation on Sexual Maturation and Reproductive Functions of Growth Hormone Receptor Knockout Mice. 2004, Honors Theses. Paper 337

[16] Poretsky L. The Insulin-Related Ovarian Regulatory System in Health and Disease.

Endocrine Reviews, 1999, 20 (4): 535-582 https://doi.org/10.1210/edrv.20.4.0374

[17] Parra A, Godoy H, Ayala J, Ramirez A, Coria I, Espinosa de los Monteros A Opposite effects of breakfast vs. oral glucose on circulating androgen levels in healthy Women. Arch Med Res, 1995, 26:379-383

[18] Kadhom J. Kata, Hazim I. Al-Ahmed, Rasha A.Mahood. Effect of trigonella foenumgraecum extract on some histological and physiological (fertility) traits white albino mice. Iraqi J. Biotech. 8 (3): 704-712(2009).

[19] Monniaux1 D., Caraty A., Clément F., Dalbiès-Tran R., Dupont J., Fabre S., Gérard N., Mermillod P., Mongets Uzbekova P. Développement folliculaire ovarien et ovulation chez les mammifères Inra Prod. Anim., 2009, 22 (2), 59-76

[20] Françoise HULOT, J. C. MARIANA and G. GATTIAU. Effet du génotype, de l'âge de la saison sur les follicules préovulatoires de la lapine 8 heures après la saillie, Reprod. Nutr. Dévelop., 1985, 25 (1A), 17-32. DOI : https://doi.org/10.1051/rnd:19850102.

\section{How to cite this article:}

Chentouh S, Boulahbel S, Ouldjoui A, Hammoudi N, Djebaili H, Adjal F. Effect of organic extracts of bunium incrassatum on the hematological, ovarian and uterine parameters of mature female rabbit. J. Fundam. Appl. Sci., 2017, 9(3), 1618-1633. 